\title{
The hotel's responsibilities in actualizing environtmental justice: the study of CSR practice on 5-star hotel environmental conservation
}

\author{
Dicky Sumarsono ${ }^{*}$, Bani Sudardi ${ }^{2}$, Warto Warto $^{3}$, and Wakit Abdullah ${ }^{4}$ \\ ${ }^{1}$ Postgraduate Program in Cultural Studies, Sebelas Maret University, Ir. Sutarmi 36A Street, \\ Surakarta 57126, Indonesia \\ ${ }^{2}$ Department of Indonesian Literature, Sebelas Maret University, Ir. Sutarmi 36A Street, Surakarta \\ 57126, Indonesia \\ ${ }^{3}$ Department of History, Sebelas Maret University, Ir. Sutarmi 36A Street, Surakarta 57126, \\ Indonesia \\ ${ }^{4}$ Department of Sociology, Sebelas Maret University, Ir. Sutarmi 36A Street, Surakarta 57126, \\ Indonesia
}

\begin{abstract}
The activity of a company can create jobs, generate products, and encourage the economic growth. However in the other hand, it inflicts social problem and disruption of the environmental conservation. Hotel is built using material from selected natural resources. However, it reduces the beauty and the balance of other natural resources. Thus, the hotel has asocial responsibility to preserve the environment and to embody the social justice in the hospitality business. The stakeholder theory states that a company is not an entity that only operates for its own sake, but also has to provide benefits for its stakeholder. The social responsibility in the environmental justice of the hospitality industry in Surakarta city is directed at; (1) Community empowerment rather than environmental preservation, this is intended to branding the hotel companies, (2) The implementation of CSR activities as a manifestation of the environmental justice is carried out by hotel's public relation itself rather than by the third parties, (3) The average of social responsibility nominal exceeds $2,5 \%$ of the statutory obligation because at the same time, the social responsibility is used for the development of the company's image.
\end{abstract}

\section{Introduction}

Law no. 32 of 2009 on Environmental Protection and Management, states that sustainable development is a development that can meet the needs of the current generation without reducing the needs of future generation by integrating the economic, social and environmental issues. This notion becomes important if the idea of necessity and

\footnotetext{
*Corresponding author: dickysumarsono@gmail.com
} 
limitation turn to be the premise of sustainable development. In this millennium era, the business world as a profit-oriented institution as well as a supporting of development and macroeconomic growth is in a dilemma. In other hand, it is demanded as the booster of economic growth and driving the environmental preservation. Hence, that the problem of justice in business is still an important topic [1].

The purpose of this research is to rove the role of the hotel in realizing environmental justice. In this millennium era, business is a profit-oriented institution as well as the support for development and macroeconomic growth, is now in a dilemma. On the other hand, it is demanded as the economic growth supporter and driving the environmental sustainability, so that the problem of justice in business yet still an important topic.

In Indonesian business world, mostly companies are privately owned in the form of PT, CV, NV or individuals (business entities). Even though the company is already Go Public, the company's controllers remain individuals, families or groups. The business entity in running its business using individual principles is not the member welfare principles. With this condition injustice arises within the company, not only for the employees, consumers and the community, but also the environment. It cannot be denied that the company's activities can create jobs, generate products, encourage economic growth, but on the other hand, it inflicts social problems and disruptions to environmental conservation [2]. With the existence of Law No. 40 of 2007 concerning The Limited Liability Companies, especially Article 74 paragraph (1), which explains that the corporation or company in running its business activities in the field and/or relating to natural resources, is obliged to carry out Social and Environmental Responsibility. The issue of Corporate Social Responsibility (CSR) is a matter of justice and natural balance. Corporations have been viewed as institutions or individuals who take the most portion of the nature. Because it takes the most portions, many other natural and human beings are disadvantaged. Thus, to maintain this natural balance, through The Word Commission on Environment requires every company in business activities for always considering the principles of sustainable development that relies on economic growth, environmental protection, and social equality, or known as the Triple Bottom Line (TBL), namely Economic benefits (profit), Environmental sustainability (planet) and Community welfare (people) [3-4].

Recognized or not, the company is the reason of environmental damaging, this can be seen by the company's waste, the atmosphere or noise of the company, the condition and situation of the company when operating, and the pollution of the company that can cause the community to feel disturbed. If the community assumes that the company does not take notice to social and environmental aspects and does not feel direct contributions that causes the community feels the negative impact, then these conditions create a sense of disbelief in the community and able to damage the company's image. This is a major issue of the need for companies to carry out CSR activities.

For the hotels, CSR programs are a form of corporate commitment to set aside corporate assets to reduce the negative impact of the company's operations on all interested parties. Various CSR activities aim for developing productive societies. CSR Hotels are divided into three target groups, namely; (1) Educational Development, (2) Empowerment of the poor, (3) Environmental Rescue. Hotels built using materials from selected natural resources will certainly reduce the beauty and balance of other natural resources. Therefore the hotel has a social responsibility in preserving the environment. Therefore, this study is to explain the realization of justice in the hospitality business through Corporate Social Responsibility in Surakarta City. Thus, the research question put forward is "How is the implementation of 5-star hotel social responsibility in environment?" 


\section{Research Methods}

The type of this research is the descriptive analytic [5] which describes the sustainable development between economic as well as environmental justice and social problems with the following concepts (Fig.1).

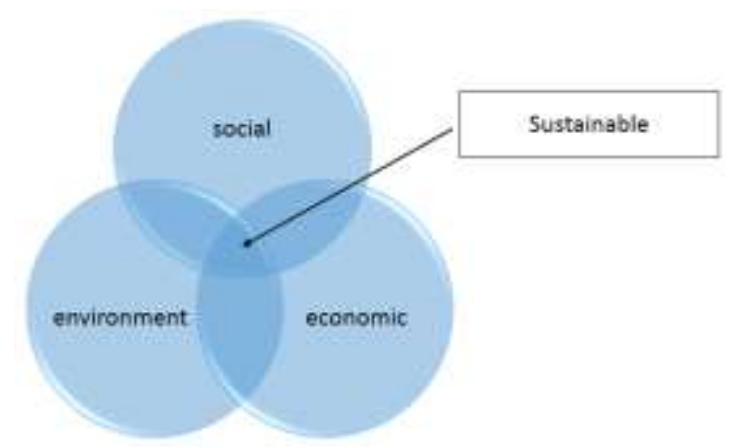

Fig. 1. Sustainable development concept.

To ensure the sustainability of the hospitality industry, it cannot be separated from environmental, social and economic. Therefore, the data collection (Table 1) in this research is through (1) The observation of objects or targets of the CSR programs in Surakarta region despite its targets are in various region, (2) Interview with 5-star hotel management, (3) studies from books, journals and reports on CSR realization of 5-star hotels (Alila Solo, Sahid Jaya Solo Hotels, KusumaSahid Prince Solo Hotels, Lorin Solo Hotels, The Royal Surakarta Solo Heritage MGallery by Sofitel).

Table 1. Data collection in research of 5-star hotel.

\begin{tabular}{|c|l|l|l|c|}
\hline No & \multicolumn{1}{|c|}{ 5-Star Hotel } & \multicolumn{1}{c|}{ Observation } & \multicolumn{1}{c|}{ Interview } & Documents \\
\hline 1 & Alila Hotel Solo & CSR Management & GM, Public Relation & CSR Report \\
\hline 2 & Lorin Hotel Solo & CSR Management & GM, Public Relation & CSR Report \\
\hline 3 & Sahid Jaya Hotel Solo & CSR Management & GM, Public Relation & CSR Report \\
\hline 4 & $\begin{array}{l}\text { Kusuma Sahid Prince Hotel } \\
\text { Solo }\end{array}$ & CSR Management & GM, Public Relation & CSR Report \\
\hline 5 & $\begin{array}{l}\text { The Royal Surakarta } \\
\text { Heritage Solo MGallery by } \\
\text { Sofitel }\end{array}$ & CSR Management & GM, Public Relation & CSR Report \\
\hline
\end{tabular}

The data analysis is using interpretative descriptive method [6]. As the interpretative parameter using the basic framework of environmental justice that built by Robbins \& Coulter [7]. The results of this qualitative research will conclude the implementation of five-star hotels in implementing environmental justice in the CSR program and to the point why the concept of environmental justice becomes a taken issue.

\section{Result and discussion}

\subsection{Environmental justice in understanding hotel management}

The establishment Environmental Justice is defined as a movement in the grassroots societies that fight for the same treatment for the people regardless of ethnicity, culture, 
socio-economic, in terms of groeth, fulfillment and enactment of laws, act and policies. Impartial treatment also means that no one or certain community is more disadvantaged by an environmental impact. Basically Environmental Justice examines the extent of the connection in the midst of between environmental and social injustice, and questions whether possible social inequity and sphere affair can be overcome using an integrated system and establishment approach. Sphere inequity is also called environmental equity which is defined as the liberties to get shelter from sphere jeopardy fairly for personal, parties, or societies unconcerned of folk, the nation or household management state.

The Environmental Justice movement or environmental justice originates from an environmental care movement that sees the other side of the environmental movement, where in the classic environmental movement attention is often focused only on pollution and physical things. While in its development, there are certain community groups that receive more exposure to contamination than other community groups. For example, in the US, commonly the location of garbage disposal is placed in the colored people resident area and not around the white people. This condition strengthen the movement to unite environmental issues and social conditions.

The integration of issues between the physical and social environment led to a combination of approaches to human rights advocacy and environmental problem. The environmental inequity motion is becoming firmer when the world society acknowledges the liberties of the healthful environs as part of the third generation of human rights agreed upon in the 1993 Vienna Convention along with the liberties of establishment. So that the term of establishment is not only attached to environmental issues (sustainable development), but also attached to human rights themselves [8].

\subsection{Hotel as environmental stakeholders}

The Stakeholder theory states that a company is not an entity that only operates for personal purpose but must be able to provide benefits for its stakeholders. The presence of a corporation is very affected by the endorsement served by the stakeholders of the corporation. The stakeholders referred to include the community, employees, government, suppliers, and others. The company has the obligation to assist the wants and needs of its stakeholders, especially stakeholders who have power over the availableness of the origins used for the corporation's operational activities, such as manpower, markets for the corporation's yield and others. One strategy that the company uses to maintain its relationships with stakeholders is by disclosing social and environmental information.

Stakeholders, both internal and external, can affect or be affected by the corporation either explicitly or implicitly. Stakeholders are both internal and external parties, their existence is very influential and influenced by the company. The first thing about stakeholder theory is that stakeholders are the order that are directly based on viewpoint about a corporation and its environment, recognizing the interplay between the two is complex and dynamic.

Hotels as profit organizations have interaction from social relations in the form of commitment and liability. Hence, the corporation has liability to its stakeholders. The liability's behavior is set on by the connection between stakeholders and the corporation. The company's social environment is a medium for companies to negotiate relationships with stakeholders. According to the stakeholder theory, the company cannot get away from the social milieu. Corporates need to preserve the authenticity of stakeholders and place them in the policy framework and judgement making, so as to support the accomplishment of company goals, namely business constancy and going concern guarantee. 
The issue of deteriorating environmental damage nowadays, changes the mindset of corporate stakeholders in CSR programs, especially on the issue of global warming, forest destruction, environmental balance. The efforts for environmental rescue that are done by corporations, are the managers' awareness towards the impact of the company's operations on the natural environment. With corporate's stakeholders, especially the Managers, they will think about what impacts will affect the nature of the products produced. In the field of hospitality, for example, there are many ways to do it, starting with a simple one, which is to persuade hotel guests for not changing the towels every day, to use construction of hotel buildings that are environmentally friendly. For example the construction of a cement board can reduce the sun's heat that entering the room, so it saves indoor air conditioning. For addition, the provision of hot water for the guests needs with solar systems, so it does not use electricity.

Since the first time it was formulated in 1987, the concept of sustainable development or sustainable development has begun to be used in many countries. With the concept of sustainable development, it begins to develop awareness of the importance of corporate responsibility towards the surrounding its business environment. The principle of sustainability is to build to fulfill the present needs without sacrificing the needs of future generations [9]. Therefore this can be achieved if the company in running its business is not only oriented to profit / profit received and ignored environmental and social aspects.

\subsection{Environmental justice practices in CSR programs at 5 star hotels}

Conceptually, the area or scope of CSR varies depending on what goals the company wants to achieve. CSR carried out by 5 -star hotels in Surakarta City covers; the field of education and health, empowerment of the poor and saving the environment and the present, the area that becomes the focus of environmental rescue. In the management of hotel operations, environmental rescue services are applied. For example, every day a lot of water and soap are needed in washing the guest room towels. Therefore, to reduce the effects of environmental pollution, the hotel gives an appeal and education for the guests who stay so that they will use the same hotel towels during their stay and not ask for new ones. Although it is only in the form of appeals or invitations, to the value of education is emphasized, so that the guests also understand about the environment rescue which is internal.

Externally, Public Relations of Lor In Hotel, Dhani Wulandari, stated that CSR is an important activity that is not only for charity, but also a commitment to be responsible for the environment and the surrounding environment. This commitment is shown by the establishment of a special department, as well as a focused program that prioritizes environmental safety and community welfare and invites hotel guests and all colleagues from the hotel to be actively involved in the framework of this sustainability development. By viewing strong commitments and Corporate Social Responsibility programs in the hotel industry, it can make important awareness of environmental sustainability. Five-star hotels work through management in implementing CSR programs with 3 fields, namely the field of environmental rescue, education and health, and the empowerment of the poor. The following are the CSR programs in 2016-2017 (Table 2).

Table 2. The CSR programs at 5-star hotels in Solo in 2016-2017.

\begin{tabular}{|c|l|l|l|}
\hline No. & \multicolumn{1}{|c|}{ Name of Hotel } & \multicolumn{1}{|c|}{ CSR Program } & \multicolumn{1}{c|}{ Information } \\
\hline 1. & Alila Hotel Solo & Education & Educational assistance \\
\hline 2. & Sahid Jaya Hotel Solo & Empowerment & $\begin{array}{l}\text { The surrounding } \\
\text { community assistance }\end{array}$ \\
\hline
\end{tabular}




\begin{tabular}{|c|l|l|l|}
\hline 3. & $\begin{array}{l}\text { Kusuma Sahid Prince Hotel } \\
\text { Solo }\end{array}$ & $\begin{array}{l}\text { Environment \& } \\
\text { education }\end{array}$ & $\begin{array}{l}\text { Community assistance } \\
\text { and reforestation of the } \\
\text { city }\end{array}$ \\
\hline 4. & Lorin Hotel Solo & $\begin{array}{l}\text { Environment \& } \\
\text { empowerment }\end{array}$ & $\begin{array}{l}\text { Waste management and } \\
\text { reforestation }\end{array}$ \\
\hline 5. & $\begin{array}{l}\text { The Royal Surakarta } \\
\text { Heritage Solo MGallery by } \\
\text { Sofitel }\end{array}$ & Empowerment & $\begin{array}{l}\text { Poor community } \\
\text { assistance }\end{array}$ \\
\hline
\end{tabular}

Of the five 5-star hotels which CSR is used for the environmental preservation is quite minimal, it is more on educational assistance and empowerment. In the environmental conservation, it ranges from reforestation activities, improvement of city parks around the hotels, waste management and enhancement of urban slum facilities. The majority of 5-star hotels' CSR is used to financing education (charity) and empowering the poor through capital assistance and training. The following are the forms of CSR activities carried out by five-star hotels in 2016-2017 (Table 3).

Table 3. The forms of CSR activities carried out by 5-star hotels in 2016-2017.

\begin{tabular}{|c|c|c|}
\hline No. & Name of Hotel & CSR Activity \\
\hline 1. & Alila Hotel Solo & $\begin{array}{ll}\text { 1. } & \text { Clining blitz social service } \\
\text { 2. } & \text { Child Foundation Assistance } \\
\text { 3. } & \text { Assistance for Permata Hati Baby Foundation }\end{array}$ \\
\hline 2. & Sahid Jaya Hotel Solo & $\begin{array}{l}\text { 1. Sharing of food for iftar during Ramadan } \\
\text { 2. Assistance for Pesantren Kilat } \\
\text { 3. Mosque Repair Assistance }\end{array}$ \\
\hline 3. & Kusuma Sahid Prince Hotel & $\begin{array}{ll}\text { 1. } & \text { Science Film Festival } \\
\text { 2. } & \text { Educational assistance for outstanding students } \\
\text { 3. } & \text { City Park assistance } \\
\text { 4. } & \text { Waste management assistance } \\
\end{array}$ \\
\hline 4. & Lorin Solo Hotel & $\begin{array}{ll}\text { 1. } & \text { Tree Planting in Balai Kambang } \\
\text { 2. } & \text { Tree Planting on Merapi Merbabu } \\
\text { 3. } & \text { Assistance for the Homes of the Blind } \\
\text { 4. } & \text { Supeltas/Volunteer traffic controllers } \\
& \text { assistance } \\
\text { 5. } & \text { Childcare Foundation assistance } \\
\end{array}$ \\
\hline 5. & $\begin{array}{l}\text { The Royal Surakarta } \\
\text { Heritage Solo MGallery by } \\
\text { Sofitel }\end{array}$ & $\begin{array}{ll}\text { 1. } & \text { Poor community assistance } \\
\text { 2. } & \text { Cultural figures assistance }\end{array}$ \\
\hline
\end{tabular}

CSR programs for hotels have many advantages including: (1) Hotels get good image in the public eye because they are considered to care about social issues such as environmental issues and community welfare; (2) the community and management feel like they own the hotel and this program fosters loyalty; (3) the existence of an environmental rescue program, hotels that rely on nature will increase their selling value. The lack of implementation of environmental conservation programs in CSR programs is due to the lack of awareness of the importance of a sustainable natural environment.

\subsection{Environmental justice as business ethic}

The implementation of environmental justice can raise environmental critical issues that need to get the interest of all parties, including the industrial world. Often the implementation can be hampered, because the merits cannot be savored directly by the 
company, or even felt unnecessary. One approach to evaluating a company's commitment to environmental responsibility is the Shades of Green Model. The commitment of the companies that use this approach can be seen in various levels of the depth of activity that they do.

Five-star hotels should apply environmental justice in their efforts to preserve the environment with the concept of Go Green as the philosophical and ethical foundation, as well as the corporate culture. What is meant by ethics, is to regulate the behavior of a person or a group of people in a company into a Go Green as the lifestyle [10]. Ethics is understood as moral principles and values that govern the behavior of people or groups related to what is right or wrong. From the above understanding, it can be explained that ethics relates to internal values of the company and forms decisions regarding social responsibility which is related to the external environment. Ethical issues are present in a situation when the actions taken by an organization can cause benefits or losses to other parties.

According to Baron [11], what is meant by business ethics is the application of the ethical principles applied in relation to the emergence of problems in business. "Business ethics is the application of ethics principles to issues that arise in the conduct of business.". The implementation of environmental justice can be raised because of the critical environmental issues that need to get the interest of all parties, including the industrial world. The implementation frequently can be hampered, because the merits cannot be savored directly by the company, or even felt unnecessary.

Hotels need to develop environmentally friendly products, recycled products, and create a company image which products are "environment friendly" from the raw material to the final stage of the product. By taking notice to the use of resources and replacing / procuring resources, design sustainable products, the role of the company with stakeholders is maintaining good relations with suppliers who are committed to the environment. From the motive above, it can be seen whether the actual movements of the company are strategic or ethical. From the model of Go Green approach in green management, for example at the level of the activist approach, it can be said that the company has conducted business activities ethically, with moral motivation, to save the environment. Even though the management is aware that the activities that they are carrying out incur huge costs but not necessarily bring short-term benefits, actually those activities can strategically provide long-term benefits. Indeed, something that is ethical is often not strategic for the company, and conversely, something strategic is often unethical for other parties. The following is an illustration of how an environmental justice approach can be strategic but also ethical, to achieve long-term corporate goals.

\section{Conclusion}

Environmental justice is a company's commitment to environmental responsibility. The company's management commitment prevents and minimizes the negative effects of the company's activities to be part of the "Business Ethics" where environmental protection, economic growth and social equality can significantly assimilate the company's activities in accordance with management principles.

By looking at the strong commitments and CSR programs that focus on environmental justice, the Corporate Social Responsibility program in the hotel industry makes innovations that can affect operational activities, even though they have to provide special budget for the environmental preservation programs to ensure continuity and sustainability. Continuous awareness for the Corporate Social Responsibility program is seen as having an advantage with the reasons, namely: (1) the hotel group gets a good image in the public eye because the hotel is considered to care about social issues such as 
environmentally friendly issues and community welfare; (2) the participation of the hotel guests in the Corporate Social Responsibility program is very high, and this also increases the sense of belonging to the program and the loyalty in choosing the hotel as their chosen accommodation; (3) in the operation of daily hotel activities, by carrying out environmentally friendly programs, it actually reduces the costs incurred for electricity and other energy uses; (4) with the existence of an environmental rescue program, in relation to the area of hotels that rely on nature as their selling value, tourists will still visit the area and the hotel will still be able to operate for a long time.

\section{References}

1. M. Mowforth and I. Munt, Tourism and Sustainability: Development, globalisation and new tourism in the Third World (Routledge, London, 2015)

2. P.I. Gallego-álvarez and P. Eduardo. Int. Bus. Rev. (2016)

3. G. Banks, R. Scheyvens, S. Mclennan, and A. Bebbington. Third World Q. 32, 2, 245-263 (2016)

4. P. Naidoo and R. Sharpley. J. Destin. Mark. Manag. 5, 1, 16-25 (2016)

5. H.R. Bernard, Social Research Methods: Qualitative and Quantitative Approaches (SAGE Publications, Los Angeles, 2013)

6. P. Alasuutari, Researching Culture: Qualitative Method and Cultural Studies (SAGE Publications, London, 1995)

7. S.P. Robbins and M. Coulter, Management. (Pearson Education, New Jersey, 2012)

8. A.G. Wibisana. Mimb. Huk. 29, 2, 292-307 (2017)

9. Tom Waas, J. Hugé, V. Verbruggen, and T. Wright. Sustainability 3, 10, 1637-1661 (2011)

10. F. Deraman. J. Tour. Hosp. Culin. Arts 9, 2, 305-316 (2017)

11. D.P. Baron, Business and its environment- 4th ed. (Prentice Hall, New Jersey, 2003) 